\title{
Typografia i tożsamość
}

Agata Szydłowska, Od solidarycy do TypoPolo. Typografia a tożsamości zbiorowe w Polsce po roku 1989, Wrocław 2018, ss. 224.

Nowoczesna typografia miała ambicje wykraczające poza sferę estetyczną. Międzywojenni projektanci z Wielkiej Brytanii, Związku Radzieckiego, Niemiec, Holandii oraz Polski często uzasadniali swoje poszukiwania argumentami, które nie dotyczyły jedynie estetyki, lecz obejmowały o wiele szerszą wiązkę zjawisk społecznych, ekonomicznych oraz kulturowych. W ten sposób ich pracownie przeistaczały się z warsztatów artystycznych w laboratoria, gdzie miała wykuć się forma przyszłości, dostosowana nie tylko do oczekiwań obywateli, lecz także do potrzeb rządzących.

„Niebezpieczne związki” typografii i polityki to jeden z bardziej intrygujących epizodów dwudziestowiecznej sztuki, a jednocześnie wciąż niedostatecznie zbadanych. Być może wynika to ze specyfiki zjawiska sytuującego się na przecięciu kilku różnych i nie zawsze łatwych do pogodzenia dziedzin. Zsynchronizowanie tych porządków badawczych jest jednak możliwe, czego dowodzi książka Od solidarycy do TypoPolo. Typografia a tożsamości zbiorowe w Polsce po roku 1989 Agaty Szydłowskiej.

W prowadzonych tutaj rozważaniach ważną role odgrywa kategoria wspólnoty. Staje się ona swojego rodzaju zwornikiem, pozwalającym na połączenie perspektywy typograficznej z tożsamościową, czyli mówiąc inaczej - na zestrojenie spraw technicznych i estetycznych z problematyką filozoficzną, antropologiczną oraz socjologiczną. Z jednej strony zatem nawiązuje do refleksji spod znaku Rozdzielonej wspólnoty Jean-Luca Nancy'ego oraz Na brzegach 
politycznego Jacquesa Rancière'a, z drugiej natomiast - proponuje rozważania nawiązujące do tradycji liternictwa oraz badań nad nim.

Współczesną typografię autorka ujmuje w trzech odsłonach historycznych, które łączy z poszukiwaniem innego rodzaju tożsamości: w przypadku Solidarycy jest to tożsamość polityczna i światopoglądowa, następnie w rozdziale Pisma narodowe i lokalne skupia się na zagadnieniu tożsamości narodowych i lokalnych, by na koniec w części Typografia wernakularna pochylić się nad problemem tożsamości klasowej.

Punktem wyjścia badań Szydłowskiej jest hipoteza, że liternictwa nie należy rozpatrywać w oderwaniu od przestrzeni jego funkcjonowania. W tym również w separacji od kwestii problemu tożsamości zbiorowych, które we współczesnym społeczeństwie opierają się na symbolach wizualnych, intensyfikujących procesy wspólnotowej identyfikacji. Takiej autoidentyfikacji, oprócz utartych symboli, sprzyja również sama typografia, często stanowiąca swoisty transfer dla różnego rodzaju treści, w tym także nacjonalistycznych.

Typografia i symbole stają się często spoiwem „wspólnot wyobrażonych”" Aby ograniczona w możliwości kooperacji wspólnota mogła uzyskać poczucie przynależności, suwerenności oraz spójności ideologiczno-kulturowej, musi rozpoznawać się w systemie kodów wizualnych. Wspólnota symboliczna opiera się na takich właśnie mechanizmach, co zauważa Benedict Anderson, zwracając uwagę na połączenie druku z narodowością: „Idea «narodu» jest dziś mocno zakorzeniona we wszystkich niemal językach druku, narodowość zaś nie daje się oddzielić od świadomości politycznej”2.

Podążając tym tropem, można stwierdzić, że typografia, będąca podstawowym narzędziem druku, jest również silnie uwikłana w dyskursy władzy. Bogatsi o doświadczenia XX wieku wiemy, że odgrywa ona istotną rolę w budowaniu wspólnoty znaczeniowej, a związki między pismem i nowoczesnymi zbiorowościami są o wiele bardziej złożone niż może się wydawać na pierwszy rzut oka. Szydłowska dowodzi tego, odwołując się do dwóch kluczowych okresów w kształtowaniu się polskiej tożsamości zbiorowej: lat międzywojennych oraz przełomu 1989 roku (i dekad następnych). Pozwala to na wyraziste ukazanie związku między typografią a politycznością, a tym samym - na zbudowanie perspektywy badawczej, w której dzieje estetyki nowoczesnej (i ponowoczesnej) zostają sprzęgnięte z praktyką społecznąa ${ }^{3}$.

1 B. Anderson, Wspólnoty wyobrażone. Rozważania o źródtach i rozprzestrzenianiu się nacjonalizmu, przeł. Stefan Amsterdamski, Kraków 1997.

2 Tamże, s. 135.

3 Zob. na ten temat: P. Bürger, Teoria awangardy, przeł. Jadwiga Kita-Huber, Kraków 2006. 
Autorka konsekwentnie podkreśla uwikłanie typografii w różnorodne projekty kształtowania zbiorowych tożsamości. Wybór kroju pisma przekłada się na kulturę, ta zaś decyduje często o przynależności do określonego porządku politycznego oraz społecznego. Za przykład posłużyć może najbardziej popularny dziś w Europie krój pisma, czyli antykwa, która powszechnie identyfikowana jest z kręgiem kulturowym łacińskiej Europy. Najmocniej zaznaczyło się to w pierwszej połowie minionego stulecia, dlatego Szydłowska czerpie najbardziej wyraziste przykłady z dziejów kształtowania się dwudziestowiecznych systemów politycznych. Wskazuje na momenty historyczne, kiedy ideologia władzy znajdowała swoje odbicie w postaci reżimu pisma. Jako przykład Szydłowska przywołuje losy antykwy i fraktury w III Rzeszy, jak również projekt modernizacji pisma opierający się na zastąpieniu (przez Kemala Atatürka) persko-arabskiego zapisu języka tureckiego alfabetem łacińskim. Reforma ta przeprowadzona w Turcji w 1928 roku miała na celu przesunięcie kraju arabskiego bliżej europejskiej wspólnoty cywilizacyjnej.

Typografia jest zatem zaangażowana w praktyki polityczne, chociaż uwikłania takie nie zawsze muszą być tak oczywiste i nie zawsze przybierają charakter stricte propagandowy. W Polsce projekty te były o wiele mniej radykalne i wiązały się $\mathrm{z}$ wiązką spraw o innym charakterze. Widać to w rozdziale poświęconym pismom narodowym i lokalnym, w którym odsłonięty został szeroki wachlarz relacji między zjawiskami badanymi przez Szydłowską. Punktem wyjścia jej rozważań jest najbardziej znany epizod $w$ dziejach polskiego liternictwa minionego stulecia, czyli działalność Adama Półtawskiego, która w międzywojniu sprzęgnięta była w nierozerwalny sposób z praktykami politycznymi, ekonomicznymi i kulturowymi. Warto jednak pamiętać, w obliczu przywołanej przez autorkę postaci Półtawskiego, że obszar jego graficznej działalności był naprawdę szeroki. Tym samym Półtawskiego należy postrzegać także, jako autora papierów wartościowych, ekslibrisów, czy opracowania graficznego Unii Horodelskiej oraz dzieł wielkich romantyków.

Szydłowską interesuje jednak najbardziej znane dziś osiągnięcie Półtawskiego - zaprojektowana w latach dwudziestych Antykwa Półtawskiego. Była to odpowiedź na pojawiające się w ówczesnej polskiej publicystyce (zwłaszcza w prasie drukarskiej) postulaty dotyczące stworzenia tak zwanego „kroju narodowego". Hasła tego rodzaju ujawniały sprzęgnięcie nowoczesnej estetyki z dyskursami politycznymi i tożsamościowymi, ponieważ przejmowały od nich wyobrażenie o wspólnocie jako grupie zdefiniowanej i konsolidowanej przez imaginarium wyobrażeniowe i narracyjne. W Polsce tego rodzaju przedsięwzięcie miało zresztą charakter nieco inny, bo opracowanie kroju narodowego dla państwa, które odradza się po 123 latach niewoli, wpisywało się w projekty związane z odbudową kraju, niepozbawioną imperialno-mocarstwowych ambicji. 
Powstaniu antykwy przyświecał cel dostosowania fontu do specyfiki naszego języka. Stworzony krój miał niwelować nierównomierną szarość, odpowiedni wygląd liter ze znakami diakrytycznymi oraz zastępować dominujące do tej pory w zapisie polskich liter skosy - obłościami i pogrubionymi pionowymi liniami sąsiadujących często ze sobą liter, takich jak: „w”, „y”, czy „k”4. Ale specyfika warsztatu literniczego to zaledwie punkt wyjścia do rozważań na temat związków typografii i tożsamości, bo jak pokazuje autorka do przeinaczonej (poddanej politycznej obróbce) idei Półtawskiego nawiązują, zarówno późniejsze, jak i współczesne kroje pism oraz idee stworzenia kroju narodowego. Ideologia narodowa potrzebowała (i wciąż potrzebuje) form wizualnej ekspresji, zaś w tworzeniu takich krojów, autorka zauważa pewne zagrożenie oraz narzędzie nie zawsze bezpiecznych praktyk normatywnych związanych $\mathrm{z}$ regulowaniem granic tożsamości zbiorowych.

Napięcia takie są najbardziej widoczne w momentach kryzysów społecznych i politycznych. W dwudziestowiecznej historii konflikt systemów wartości bardzo często miał swój mniej lub bardziej widoczny ekwiwalent w formie wizualnej, walka z dominującą ideologią często kumulowała się w symbolach graficznych, logotypach, inskrypcjach na murach, jak również innych formach oznaczania przestrzeni publicznej (i naruszania regulującego ją ładu).

W Polsce lat 80 . tego rodzaju związek między sprawami politycznymi a typografią był bardzo złożony, zaś jednym z najbardziej znanych wizualnych form oporu przeciw władzy stała się solidaryca. W rozdziale poświęconym temu krojowi Szydłowska referuje w syntetyczny sposób najistotniejsze fakty związane z jego powstaniem. Solidaryca to przykład quasi-kroju pisma, jakim Jerzy Janiszewski posłużył się do zaprojektowania hasła „Solidarności”. Intensywność zaangażowania protestujących podczas wydarzeń na terenie Stoczni Gdańskiej zainspirowała go do stworzenia wizualnej reprezentacji uciemiężonego ludu robotniczego. Tak narodziło się w sierpniu roku 80. logo NSZZ „Solidarność”. Stało się ono rodzajem odpowiedzi na faktyczną potrzebę zespojenia wspólnotowego wynikłego z kontekstu społecznych i politycznych przemian. A jednocześnie manifestem Janiszewskiego wyrażającym jego wsparcie dla strajkujących. Odtwarzając w sposób syntetyczny historię typograficznego fenomenu, jakim okazała się solidaryca, autorka uzupełnia niedookreślenia i luki w naszej wiedzy na temat spraw o charakterze ulotnym, wciąż silnie związanych z krystalizowaniem się współczesnej polskiej tożsamości.

Stworzona w momencie burzliwych przemian ustrojowych solidaryca stanowi przykład pisma o dwuznacznym charakterze. Szydłowska słusznie zauważa,

4 J. Sowiński, Adam Póttawski. Typograf artysta, Wrocław 1988, s. 193. 
że nie została ona zaprojektowana do funkcjonowania w obiegu typograficznym, jej charakter jest więc otwarty. Wzbogacane przez ostatnie 30 lat licznymi nawiązaniami oraz trawestacjami dzieło Janiszewskiego było ciągle poddawane niekontrolowanemu procesowi uzupełniania. Szydłowska pogłębia również rozpoczęte w Paneuropie ${ }^{5}$ rozważania nad symbolicznym charakterem solidarycy (używana w kontekście protestów związanych z zaostrzeniem prawa aborcyjnego czy mniejszości seksualnych) oraz jej politycznym wydźwiękiem.

Solidaryca zostaje przedmiotem licznych nawiązań ze względu na swoją rozpoznawalność i głęboką warstwę znaczeniową, których kolebką jest jej polityczny rodowód. Nic więc dziwnego, że stała się graficzną formą odpowiedzi na wiadomość o pochodzeniu zamówionych z okazji obchodów 25-lecia pierwszych wolnych wyborów koszulek z Bangladeszu. W tej atmosferze skandalu nieposzanowania cudzej wolności narodziło się hasło: „Bangladeszowość”, mające charakter internetowego memu. Oddająca dezaprobatę przeciwko wyzyskiwaniu robotników fabryk w Azji i Ameryce Południowej, pracujących na zysk europejskich i amerykańskich firm, „Bangladeszowośc”, przyjmując reprezentację graficzną hasła Janiszewskiego, funkcjonuje jednak jako jego semantyczny antagonista. Jeszcze inną trawestacją do wolnościowej solidarycy jest stworzone na potrzeby identyfikacji wizualnej Węgierskiego Ruchu Solidarności logo „Szolidaritás". Powinowactwo węgierskiego odpowiednika nie pozostawia wątpliwości i stało się przyczynkiem do sporów na tle nie tylko politycznym, ale również znaczeniowo-ideologicznym ze względu na symboliczne obciążenie solidarycy. Nie stanowi ona bowiem kroju pisma o pełnym zestawie znaków, a także możliwego do ujednolicenia i ustalenia w formie niezmiennej, bez utraty jej otwartego charakteru. A jednocześnie jako głos większości i środowisk politycznych staje się znakiem władzy oraz dominacji. Być może w tym również leży (na początku zaznaczony przez autorkę) problem z jej wykorzystywaniem przez inne ruchy czy społeczności.

Rozważania Szydłowskiej na temat związków typografii i tożsamości zbiorowych przybierają również inną postać. W rozdziale Typografia wernakularna omawia w bardzo intrygujący sposób związek między tożsamością klasową a typografią. Okres od pierwszych wolnych wyborów w 1989 roku wiąże również z profesjonalizacją sztuki graficznej, powrotem wolnych mediów oraz dojściem do głosu nowych zbiorowości, które posługują się typografią w celu swojej identyfikacji. Związek porządku klasowego i liternictwa zauważa Szydłowska zwłaszcza w typografii wernakularnej - lokalnej, rdzennej, prostej, naiwnej,

5 A. Szydłowska, M. Misiak, Paneuropa, Kometa, Hel. Szkice z historii projektowania liter w Polsce, Kraków 2015. 
która funkcjonując obok typografii profesjonalnej. Przykładem odejścia od tożsamości narodowych w stronę kontekstu lokalnego jest zjawisko „TypoPolo”, czyli nieprofesjonalnego liternictwa towarzyszącego małym przedsiębiorstwom, który to termin stworzył grafik Jakub „Hakobo” Stępień6.

Odwołując się do źródłosłowu neologizmu - mamy tu do czynienia z typograficznym odpowiednikiem disco polo. Jest więc „TypoPolo” polską typografią, będącą składową graficznej sfery użytkowej miasta, stanowiącego przestrzeń publiczną o budowie palimpsestowej:

"TypoPolo” jest neologizmem powstałym z połączenia terminów „typografia” i „disco polo" [...] TypoPolo stało się zatem typograficznym odpowiednikiem disco polo, liternictwem, które w oczach niektórych jest brzydkie, irytujące, wywołujące zażenowanie i kpiny, choć zarazem popularne i wszechobecne. Sama nazwa odsyła do skojarzeń z kulturą niską, zaściankową, gorszą. ${ }^{7}$

Szydłowską interesuje nie tyle samo pojęcie, co kontekst, w jakim jest używane, w związku z tym wskazuje na różne możliwości określenia typografii mianem „TypoPolo” w zależności od tego, czy jako kryterium przyjmie się kategorię wernakularyzmu, czy nacisk zostanie położony na jakości estetyczne.

Opierając się na tym przykładzie, Szydłowska pokazuje, w jaki sposób typografia i formy wizualne zostały formami społecznej dystynkcji ${ }^{8}$. Po 1989 roku estetyka stała się narzędziem do budowania i utrwalania nowych hierarchii społecznych, które nie zawsze traktowały opisywany przedmiot z należną uwagą i wrażliwością. Sam system wartości estetycznych, staje się w przypadku kategorii „TypoPolo” formą opresji i kolejnego rodzaju reżimu, tym razem reżimu nieprzystawalnych regul, które prowadzą w perspektywie społecznej do dyskryminacji tegoż zjawiska. Chociaż wernakularne liternictwo staje się również inspiracją dla twórców profesjonalnych:

Gest umieszczenia obok siebie, w jednej przestrzeni, prac wykonanych przez pozbawionych graficznej ekspertyzy i zaplecza instytucjonalnego właścicieli sklepów lub zakładów usługowych oraz prac, które odnoszą się do nich na metapoziomie, uwydatnił nierówności społeczne i dysproporcję wiedzy oraz statusu. ${ }^{9}$

Szydłowska wyraźnie sprzeciwia się ujmowaniu „TypoPolo” w kategoriach estetycznych, które całkiem nie przystają do zjawiska stworzonego z powodów czysto utylitarnych oraz przy użyciu dostępnych materiałów. Tak rozumiana

6 Tamże, s. 186.

7 A. Szydłowska, Od solidarycy do TypoPolo. Typografia a tożsamości zbiorowe w Polsce po roku 1989, Wrocław 2018, s. 179.

8 P. Bourdieu, Dystynkcja. Społeczna krytyka władzy sqdzenia, przeł. P. Biłos, Warszawa 2005.

9 A. Szydłowska, Od solidarycy do TypoPolo..., dz. cyt., s. 189. 
lokalność nie jest wytwarzana przez tożsamościowe dyskursy, nie powiela też mechanizmów charakterystycznych dla „wspólnot wyobrażonych”, lecz powstaje w sposób oddolny i spontaniczny. Tego rodzaju typografia wernakularna stała się nieodłącznym towarzyszem pejzażu czasów transformacji, urastając do rangi jednego z jej najbardziej charakterystycznych elementów, które nie przystają do wypracowanych wcześniej kategorii badawczych oraz wymykają się jednoznacznej ocenie badaczy kultury współczesnej.

\section{Bibliografia}

Anderson B., Wspólnoty wyobrażone. Rozważania o źródtach i rozprzestrzenianiu się nacjonalizmu, przeł. Stefan Amsterdamski, Kraków 1997.

Bourdieu P., Dystynkcja. Społeczna krytyka władzy sadzenia, przeł. P. Biłos, Warszawa 2005.

Sowiński J., Adam Póttawski. Typograf artysta, Wrocław 1988, s. 193.

Szydłowska A., Od solidarycy do TypoPolo. Typografia a tożsamości zbiorowe w Polsce po roku 1989, Wrocław 2018.

Szydłowska A., Misiak M., Paneuropa, Kometa, Hel. Szkice z historii projektowania liter w Polsce, Kraków 2015. 